\title{
The Jurassic-Cretaceous boundary in Boreal Russia: radiolarian and calcareous dinoflagellate potential biomarkers
}

\author{
Valentina S. VISHNEVSKAYA ${ }^{1, *}$ \\ 1 Geological Institute, Russian Academy of Sciences, Moscow, 119017 Russia
}

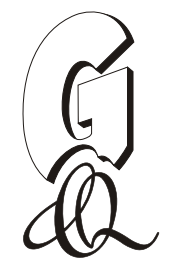

Vishnevskaya, V.S., 2017. The Jurassic-Cretaceous boundary in Boreal Russia: radiolarian and calcareous dinoflagellate potential biomarkers. Geological Quarterly, 61 (3): 641-654, doi: 10.7306/gq.1370

\begin{abstract}
The International Berriasian Working Group (ISCS) suggested primary and secondary marker "datums" to fix the basal Berriasian boundary and thus to define the Jurassic-Cretaceous boundary (Wimbledon et al., 2011, 2013). Two primary markers Calpionella, as well as calcareous nannoplankton, are practically unknown in the Boreal Realm. Testing and calibration of these markers, as well as of fossils of radiolarians and other signals, in the most complete sections, were declared as an important task for the near future. In the Tethys, the Jurassic-Cretaceous boundary based on radiolarians falls inside zone UAZ 13 of Baumgartner et al. (1995), whereas in the palaeo-Pacific it corresponds to the boundary between zones 4 and 5 of Pessagno et al. (2009), and in boreal Siberia it probably falls between the biohorizons of Parvicingula haeckeli and P. khabakovi. The radiolarian events at the Jurassic-Cretaceous boundary in the boreal successions of Russia can be proposed to be used as an additional biomarker to help develop new integrated boundary criteria. Thus, as the first appearance of the zonal species Calpionella alpina, which defines the Jurassic and Cretaceous boundary, coincides with the first occurrence of the calcareous dinocyst zonal species Stomiosphaerina proxima (Reháková, 2000), it is logical to propose a calcareous dinoflagellate, widely represented in the Upper Jurassic-Lower Cretaceous Bazhenovo Formation of Siberia, as a secondary marker.
\end{abstract}

Key words: Tithonian and Berriasian stages, radiolarians, calcareous dinoflagellates, Tethys, boreal, Volgian.

\section{INTRODUCTION}

The Jurassic-Cretaceous boundary interval has been problematic since the start of stratigraphic study, as reflected in different stage names being employed in the Tethyan realm and below and above the putative boundary (Wimbledon, 2008). Due to magnetostratigraphy there has been some progress in the correlation of the Jurassic-Cretaceous boundary interval from Tethys to Siberia (Nordvik) (Wimbledon et al., 2011). Moreover, Upper Jurassic to Lower Cretaceous highly bituminous shale and siliceous sequences of Western Siberia draw increasing attention, especially the Bazhenovo suite. Now it is considered as a strategically important asset in terms of prospects for the Russian oil industry (Afanasev et al., 2010). There are question marks over the lower and upper limits of deposits of the Bazhenovo suite and also over the location of the Jurassic and Cretaceous boundary within it.

In the 29th issue of ISC Decisions (1997) a resolution was published to specify the position of the Jurassic-Cretaceous boundary in the Boreal Realm and the status of the Volgian Stage, accepted at the Extended Meeting of the ISC Bureau on February 2, 1996. The accepted position of the Jurassic-Cretaceous boundary in the Boreal Realm of the Russian sector was

\footnotetext{
*E-mail: valentina.vishnaa@mail.ru

Received: January 30, 2017; accepted: May 3, 2017; first published online: July 28,2017
}

between the Middle and Upper Volgian substages. It was accepted to re-classify the Volgian Stage in the same volume from the category of a general unit into the category of a regional stratigraphic unit as a horizon (regional stage), leaving in the General Stratigraphic Scale of Russia only the Tithonian and Berriasian stages in the boundary interval (Vasileva, 2015).

The international Berriasian WG (ISCS) proposed primary markers and secondary constraining datums (Fig. 1) in order to fix a base for the Berriasian and the Jurassic-Cretaceous boundary (Wimbledon et al., 2011, 2013; Schnabl et al., 2015). The testing and calibration of these markers, as well as foraminiferal, radiolarian and other signals in the most complete and fossiliferous sections, was promoted as an important task for the near future.

The Russian Commission on the Jurassic system is working on the restoration of the inclusion of the Volgian Stage into the Jurassic System, based on new magnetostratigraphic and biostratigraphic data. The commission (on 3 April 2012) decided to recommend to ISC to replace the Tithonian Stage by the Volgian in the General Stratigraphic Scale of Russia, preserving the latter in the volume, accepted before 1996 (from the base of the llowaiskya klimovi Zone to the top of the Craspedites nodiger Zone) and to discuss this issue at a joint meeting of the commissions on the Jurassic and Cretaceous systems of the ISC (Baraboshkin et al., 2015).

The main points of this paper are:

- to examine the potential of radiolarians as additional biological markers to help define a boundary;

- to propose calcareous dinocysts as a secondary marker. 


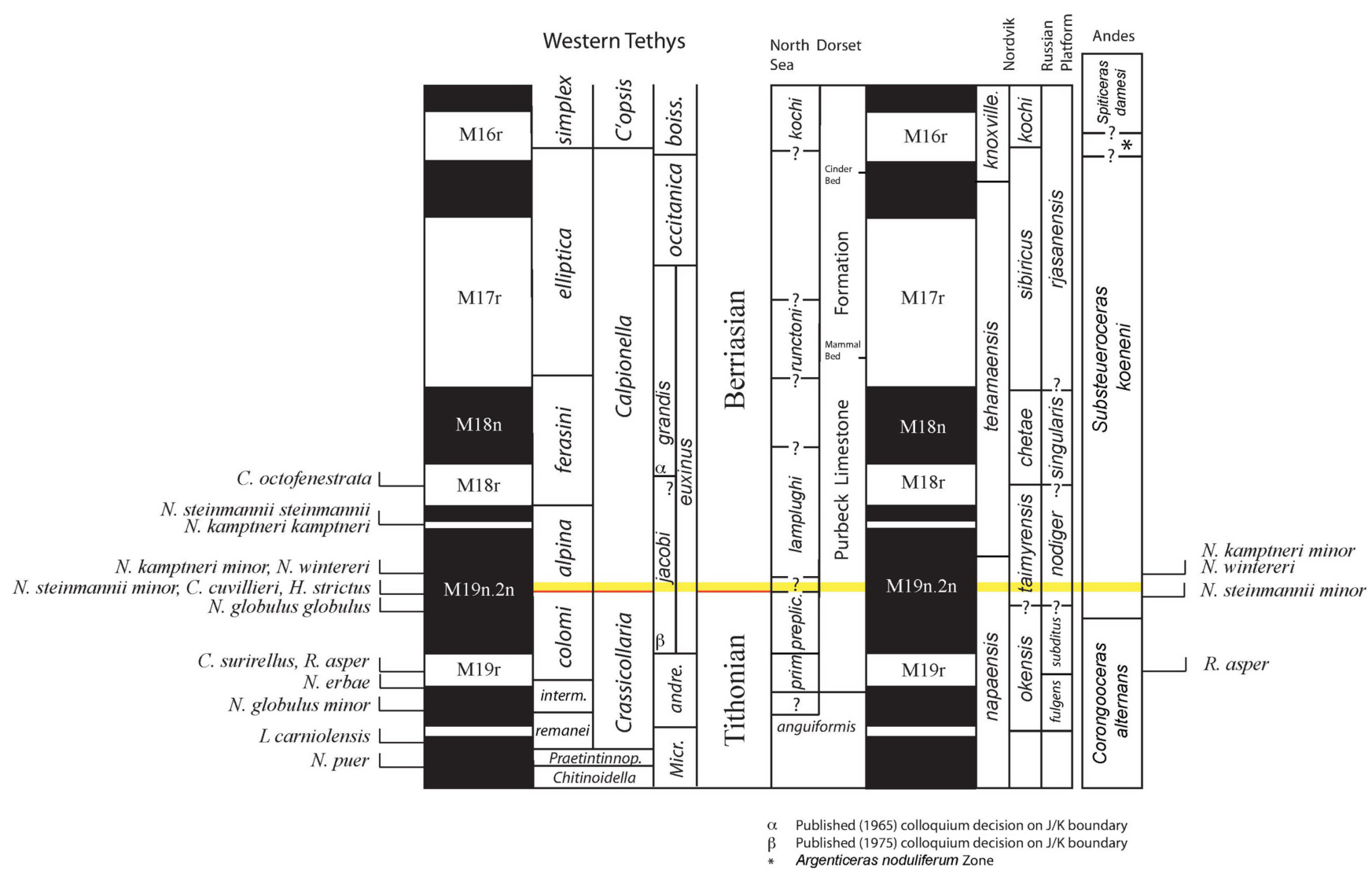

Fig. 1. Markers under examination as potentially useful in defining the Jurassic/Cretaceous interval in the Tethyan and Boreal realms (Wimbledon et al., 2011, 2013; Schnabl et al., 2015)

\section{MATERIALS AND METHODS}

Radiolarian collections were taken from 6 sections of the Russian Arctic (Vishnevskaya and Kozlova, 2012), 7 sections in the Siberian Bashenovo Formation (Panchenko et al., 2016), as well as the Lena Delta section (Vishnevskaya et al., 2014) and 24 profiles in NE Asia (Vishnevskaya and Filatova, 2012, 2016). The number of specimens examined exceeds one thousand: 44 samples come from 6 sections of the Russian Arctic, 700 samples from 7 sections in the Siberian Bashenovo Suite and the Lena Delta section, and 300 samples from 24 profiles in NE Asia. The collections are housed at the Geological Institute of the Russian Academy of Sciences.

The samples (all chert, shale, or jasper) were crushed and processed with hydrofluoric acid (5-10\%), while clay, shale and carbonate concretions were processed with acetic acid in the palaeontology laboratory of the Geological Institute, Moscow. Radiolarians were picked, mounted on cardboard slides fixed with special glue on metal stubs, and identified using a binocular microscope and a scanning electron microscope (SEM). All photographs were taken with SEM, as well as with an optical microscope.

With bituminous radiolaria-bearing sequences, we used the method of tomography, which allows one to investigate the inner and external structure of radiolarian skeletons in rocks (Fig. 2) and in thin-sections. Tomography was firstly applied in radiolarian analysis. The advantage of the tomographic method is that it allows to examine the object while rotating around both vertical axis and horizontal axes.

The calcareous dinocysts were investigated under an optical microscope.

\section{CORRELATION OF NORTH AMERICAN RADIOLARIAN ZONES WITH TETHYAN UNITARY ASSOCIATION ZONES}

Starting in the Late Jurassic there are three distinct climatic radiolarian associations. These are: Tethyan, Pacific, and Boreal. The Tethyan or Mediterranean Tethyan radiolarian fauna represents the first association with an abundance of Andromeda Baumgartner, Emiluvia Foreman, Pantanellium Pessagno (Baumgartner, 1984; Baumgartner et al., 1995; Hardenbol et al., 1998) and Ristola Pessagno and Whalen (Alps, Carpathians and Caucasus). This association is very diverse and represents low-latitude radiolarian faunas. Tethyan Unitary Association Zones (Tethyan Zones) were developed by the International Jurassic-Lower Cretaceous Group: all data published in Baumgartner et al. (1995). The second radiolarian fauna (North Pacific bioprovince) is dominantly non-Tethyan with some input of Tethyan species: the base of site 305 of DSDP in the Pacific Ocean (Vishnevskaya, 2001), California (Pessagno et al., 2000), and Mexico (Yang, 1993). North American Radiolarian Zones (Pacific Zones) were established by Pessagno (1977) Pessagno et al. (1993, 2000, 2009; cf. Yang, 1993) based on the genera Parvicingula, Mirifusus, Ristola, Caneta of the family Parvicingulidae (Fig. 3 ). The last occurrence of Parvicingula colemani and Ristola altissima was fixed in Zone 4 (Pessagno et al., 1993), the first appearance of Williriedellum ruesti and Obesacapsula rotundata was recorded in Zone 5 (Kiessling et al., 1999; Pessagno et al., 2009). The third climatic radiolarian association, a Boreal one, is characterized by the prevalence of Parvicingula and is more typical of high latitudes (Pacific Rim, Argentina, 


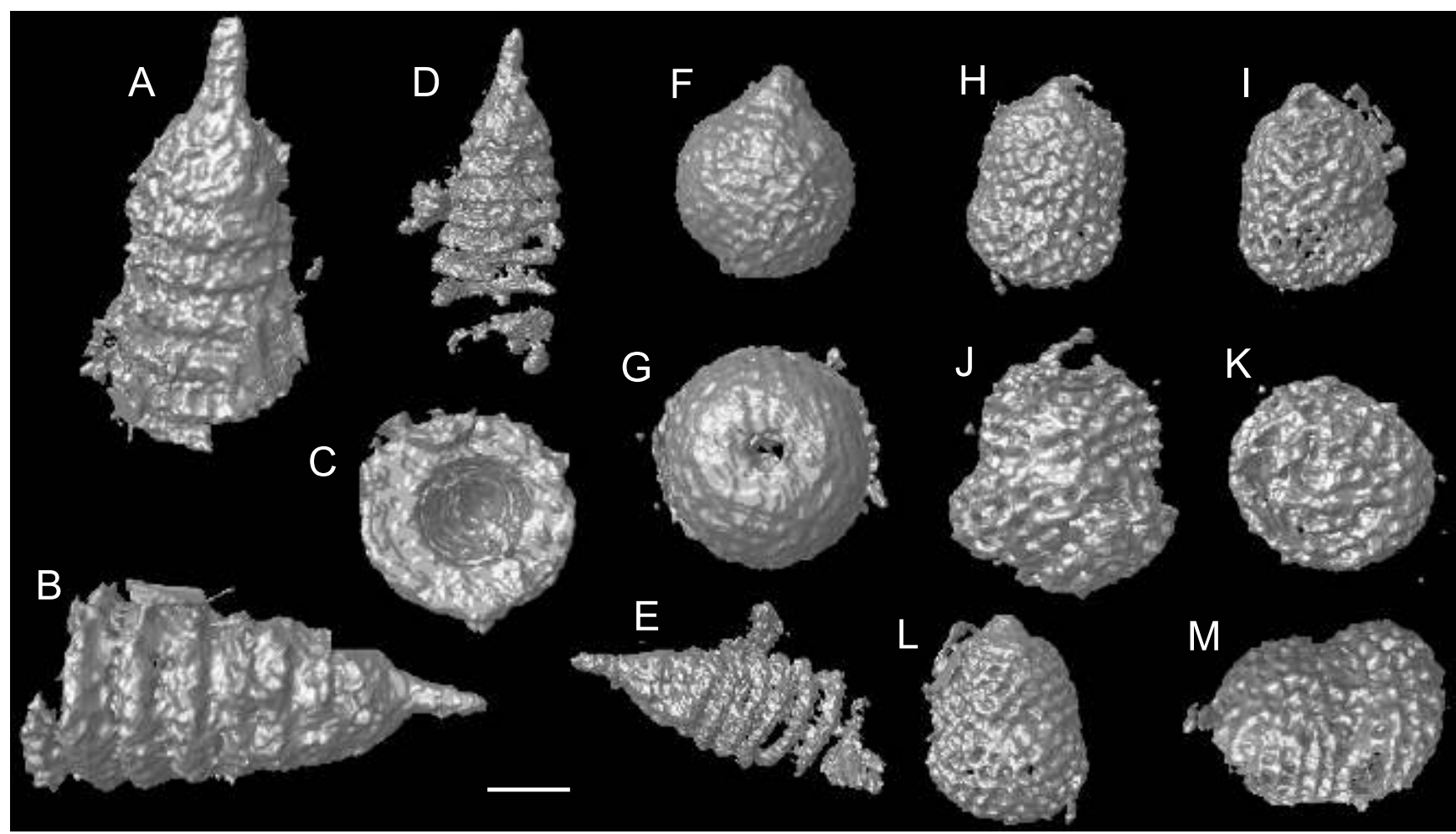

Fig. 2. Radiolarian skeletons as X-ray microtomographic images

A-C - Parvicingula haeckeli (Pantanelli); D, E - Parvicingula sp.; F, G - Williriedellum salymicum (Kozlova); H-M - Tricolocapsa campana Kiessling; A-E, sample 2-35, Western Siberia, Upper Volgian; F-M, sample 11-22, Western Siberia, Berriasian; scale bar $100 \mathrm{~m}$

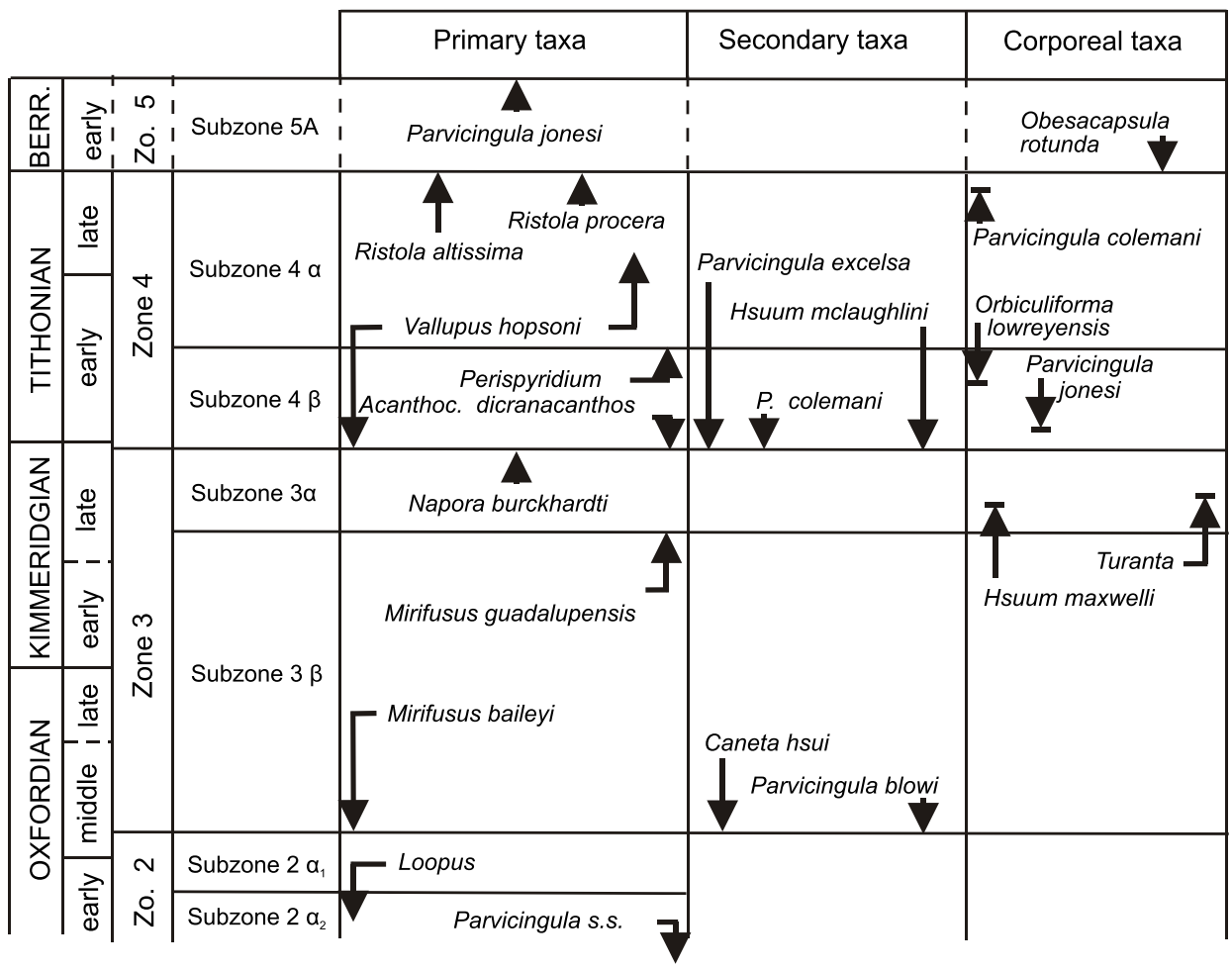

Fig. 3. Upper Jurassic and Lower Cretaceous radiolarian zonation of Pessagno et al. $(1993,2009)$ 
northern European and Siberian platforms). This association is widespread in the Volga River Basin of the Russian Platform (Vishnevskaya and Baraboshkin, 2001; Vishnevskaya and Kozlova, 2012) and many areas of Western Siberia (Vishnevskaya, 1998, 2013; Bragin, 2009; Vishnevskaya et al., 2014). The genus Parvicingula is also widespread in the Arcto-Boreal province (Spitsbergen, Timan-Pechora Basin, Norway Sea and northern Siberia; Vishnevskaya and Kozlova, 2012) and Austral province of Antarctica and the Indian Ocean (site 765, 766 and DSDP site 261, Argo Abyssal Plain and Lower Exmouth Plateau; Kiessling, 1999).

Based on correlation with the first appearance of nannoconids the Jurassic-Cretaceous boundary in the Tethys (for instance, in Turkey) corresponds to first occurrences of the radiolarians Becus nodulosus (Dumitrica), Diceratosaturnalis dicranacanthos (Squinabol), Deviatus diamphidius (Foreman), Pyramispongia bormsteinensis (Steiger), Acaeniotyle diaphorogona Foreman, Emiluvia pessagnoi Foreman, Archaeodictyomitra apiarium (Rüst) sensu Kocher, as well as Thanarla sensu lato (Mekik et al., 1999; Mekik, 2000).

Due to radiolarian provincialism the correlation of radiolarian biozones between the Boreal (north of Eurasia and America) and Sub-Boreal Pacific and Tethyan realms (Mediterranean area, southern Europe) is hampered during the Late Jurassic-Early Cretaceous interval. The Jurassic-Cretaceous boundary of the Tethyan zonal scheme sits within UAZ 13 of Baumgartner et al. (1995), whereas the $\mathrm{J} / \mathrm{K}$ boundary in the Pacific North American zonal scheme (Pessagno et al., 1993, 2009) is between zones 4 and 5 (Fig. 4). These differences are likely due to the predominance of boreal faunas in North America and may be explained by different methodologies and chronostratigraphic calibration of radiolarian data in the successions.

\section{PARVICINGULIDAE AS A UNIQUE FAMILY, USED IN ALL ZONATIONS}

The family Parvicingulidae Pessagno, 1977 includes 17 genera, 11 of which originated in the Pacific palaeogeographic province. Probably Proparvicingula Carter, 1993 was the pre-

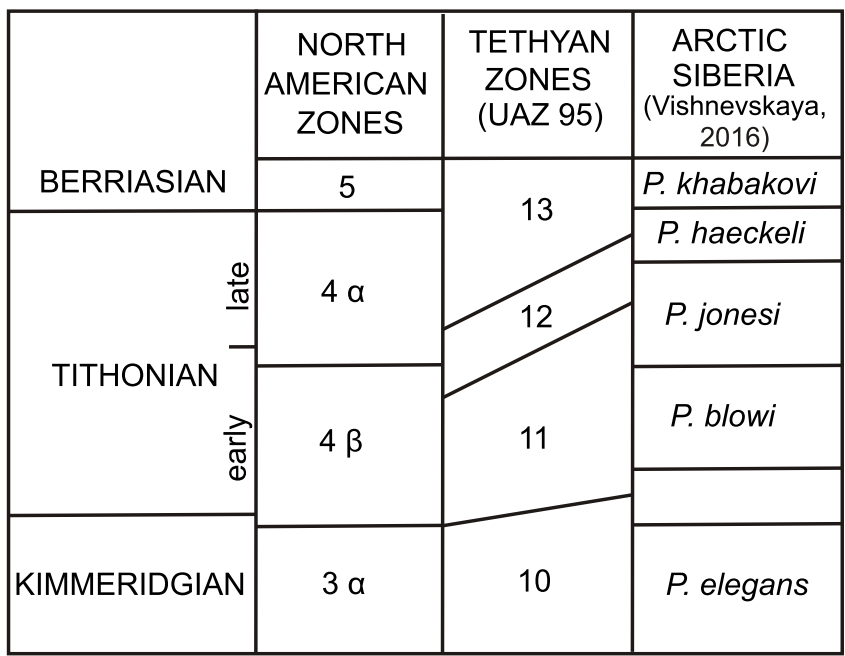

Fig. 4. Correlation of North American, Tethyan and Russian Arctic Siberian radiolarian zones after Kiessling et al. (1999) cursor of three lines within the family Parvicingulidae Pessagno (Fig. 5):

- conical-subsphaerical representatives without an apical horn and spine,

- high-conical representatives with an apical horn,

- high-conical representatives with a long apical spine.

Thus, an analysis of the geographical distribution of the Parvicingulidae showed that its high-conical representatives (Parvicingula, Proparvicingula, Praeparvicingula, Atalantria, Canelonus, Elodium, Darvelus, Nitrader, Pseudoristola and Triversus) come from the Pacific palaeogeographic province and have a mass development in boreal and natal (=Austral or southernmost Antarctic-related Zone) areas, and their areas of distribution often coincide with areas with cold-water Buchia, whereas the conical-subsphaerical group (Mirifusus, Ristola, Tethysetta, Caneta, Svinitzium, Pseudocrolanium, Wrangelium) has a primary distribution in Tethys.

It is possible that the appearance of the genus Proparvicingula Carter (and family Parvicingulidae Pessagno) was connected with cooling which began $210 \mathrm{Ma}$ (Fig. 6A). The earliest representatives of this family, excepting Proparvicingula Carter, with their first occurrence in the Rhaetian (Late Triassic), are the genera Nitrader Cordey and Carter (Hettangian-Sinemurian) and Atalantria Cordey and Carter (Hettangian-Pliensbachian) probably derived from Proparvicingula during a temperature minimum at the Triassic-Jurassic boundary (Zakharov, 2010).

At the end of prolonged Early Jurassic cooling in boreal regions, the new genera Praeparvicingula Pessagno, Blome and Hull (Middle Toarcian-Barremian) Parvicingula Pessagno and Elodium Carter (Middle Toarcian-Aalenian) made their first appearance.

The genus Proparvicingula Carter is a possible ancestor of Praeparvicingula Pessagno, Blome and Hull (Middle Toarcian-Barremian) and Parvicingula Pessagno.

The high-conical representatives of the family Parvicingulidae Pessagno also have principal stratigraphic significance (Parvicingula and Praeparvicingula alone contain together 77 species) and can be used for subdivision and correlation of sequences around the Jurassic-Cretaceous boundary.

Many species of the Parvicingulidae, such as Parvicingula blowi, $P$. colemani, $P$. jonesi, $P$. vera, Ristola turpicula, $R$. cretacea, $R$. altissima, Tethysetta depressa, Caneta hsui, Mirifusus baileui, M. guadalupensis and M. mediodilatatus are zonal markers (see Fig. 3) for the Jurassic and Lower Cretaceous (Pessagno, 1993; De Wever et al., 2001). The phylogenetic lines of the Parvicingulidae have allowed the compilation of stratigraphical zonal schemes for the Jurassic to Lower Cretaceous sequences of California (Pessagno, 1977; Hull, 1997), Argentina and Antarctica (Kiessling, 1999), as well as northern Russia (Vishnevskaya, 2001; Vishnevskaya and Murchey, 2002; Vishnevskaya and Kozlova, 2012) and the Russian Far East (Popova et al., 1999).

The ubiquitous presence of the Jurassic-Early Cretaceous genera Parvicingula and Praeparvicingula [Parvicingula blowi Pessagno, $P$. jonesi Pessagno, $P$. excelsa Pessagno and Blome, P. blomei Yang, Praeparvicingula holdsworthi (Yang), Praeparvicingula aff. sencilla Hull] in radiolarian associations of the Anyui Ocean (Vishnevskaya and Filatova, 2012, 2016), Bazhenovo (Panchenko et al., 2015), Pechora and Russian seas (Vishnevskaya and Kozlova, 2012) supports the presence of the northern seaway bringing a large number of species of these genera from the Pacific palaeoclimatic province to the 

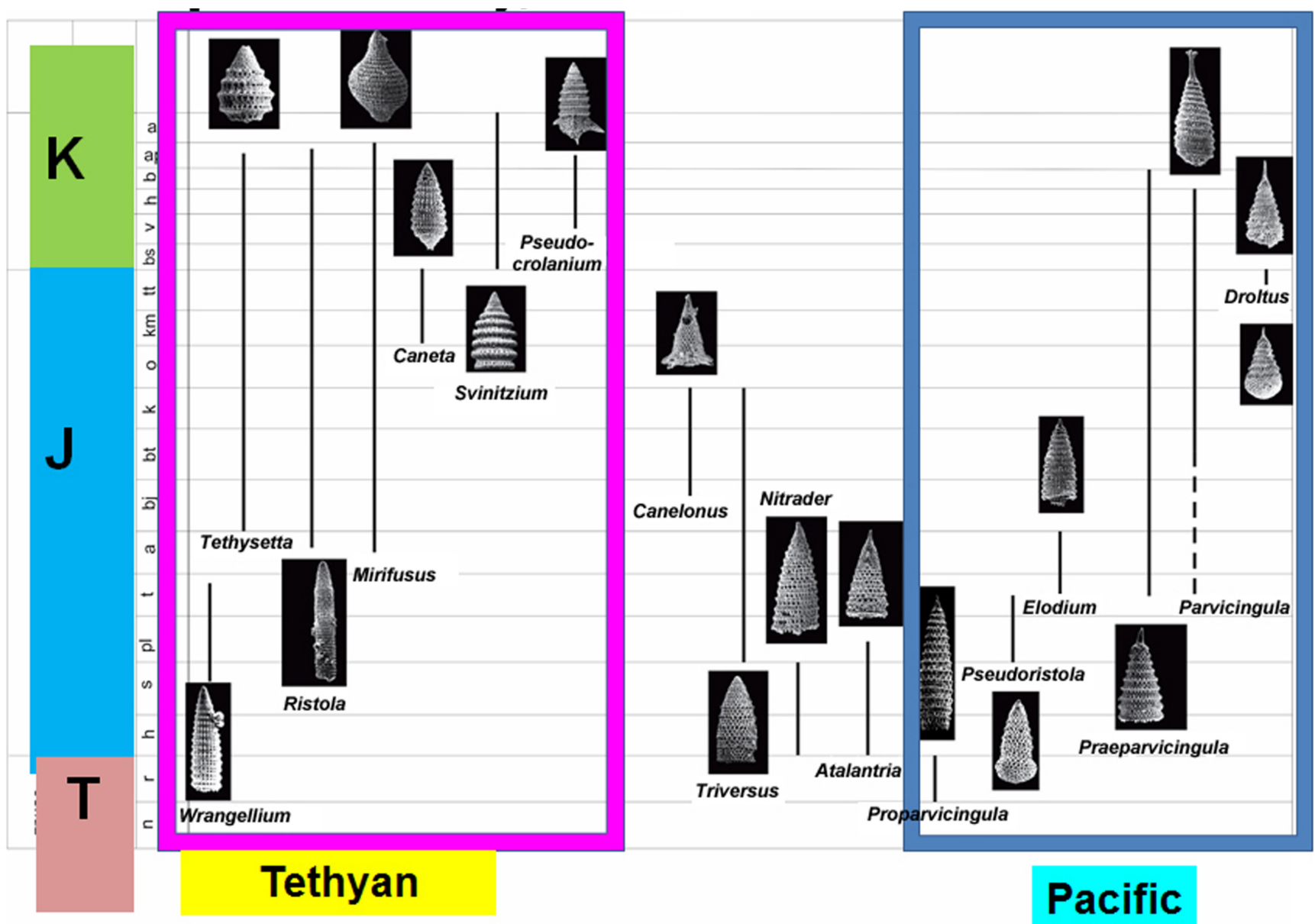

Fig. 5. The stratigraphic ranges and possible phyletic relationships of genera of the family Parvicingulidae

Boreal, Arctic (Bragin, 2011; Vishnevskaya et al., 2014) and Arcto-Boreal of the north Atlantic (Vishnevskaya and Kozlova, 2012). Only in the later Berriasian (at the end of the Volgian) time, new specialized genera - Arctocapsula, Echinocampe, Nordvikella and Spinicingula - appeared in radiolarian associations (Bragin, 2011; Vishnevskaya and Kozlova, 2012).

The group of high-conical representatives of the Parvicingulidae evolved rapidly in the course of the Late Jurassic and Early Cretaceous, spreading through the high palaeolatitudes of the entire Pacific palaeogeographic province, and even penetrating into the Arctic and Antarctic regions: whereas the conical-subsphaerical group, related to warmer episodes, coincides with Tethys, and sometimes with the ecotone zones of "greenhouse" periods (Fig. 6B).

\section{RADIOLARIAN ASSOCIATIONS AT THE J/K BOUNDARY IN BOREAL REGIONS}

So far data on the Late Jurassic-Early Cretaceous radiolarian associations of the Russian sector of northern Asia (Vishnevskaya and Pralnikova, 1999; Vishnevskaya and Filatova, 2012, 2016), as well as eastern Europe and Western Siberia (Vishnevskaya, 1993, 1997, 1998; Vishnevskaya and Pralnikova, 1999; Vishnevskaya and Baraboshkin, 2001; Vishnevskaya and Kozlova, 2012), and the Norway Sea
(Nakrem and Kiessling, 2012) with abundant Parvicingulidae (Fig. 7) have been published.

The high-conical representatives with apical horns (Fig. 8L, $\mathrm{O}, \mathrm{P}$ ), high-conical representatives with long apical spines (Fig. $8 Q$ ) together with conical-subsphaerical representatives without an apical horn and spine of the genera Mirifusus and Ristola (Fig. 8N, R-T) of the Parvicingulidae are well-known from sites on the Pacific Rim of Russia.

Typical Middle-Late Volgian (Middle Tithonian-Berriasian) radiolarians have been described from Nordvik of the Arctic coast of eastern Siberia (Zakharov and Rogov, 2006; Bragin, 2011) and Lena River Delta area (Vishnevskaya et al., 2014), where species of the endemic family Echinocampidae Bragin prevail in the Lower Cretaceous (Fig. 8).

The Middle Volgian (Middle-Upper Tithonian) radiolarian association of the ammonite Variabilis Zone includes Arctocapsula magna Bragin, A. congelata Bragin, A. constantia Bragin, Archaeospongoprunum sp. cf. A. klingi Pessagno, Higumastra turgida Bragin, Orbiculiforma sp. aff. O. teres Hull, Parvicingula sp., Praeconocaryomma sp. cf. P. spinosa Yang, Praeparvicingula sp. cf. $P$. sencilla Hull, $P$. cappa (Cortese), whereas the Upper Volgian (Uppermost Tithonian-Lower Berriasian) Chetae and Sibiricus ammonite zones contain Arctocapsula incompta Bragin, A. perforata Bragin, Echinocampe aliferum Bragin, E. cristatum Bragin, E. aculeatum Bragin, Nordvikella elegans Bragin, N. improcera Bragin, Glomeropyle polygonium Bragin, Napora pyramidalis reticulatus Bragin, Orbiculiforma sp. aff. $O$. 


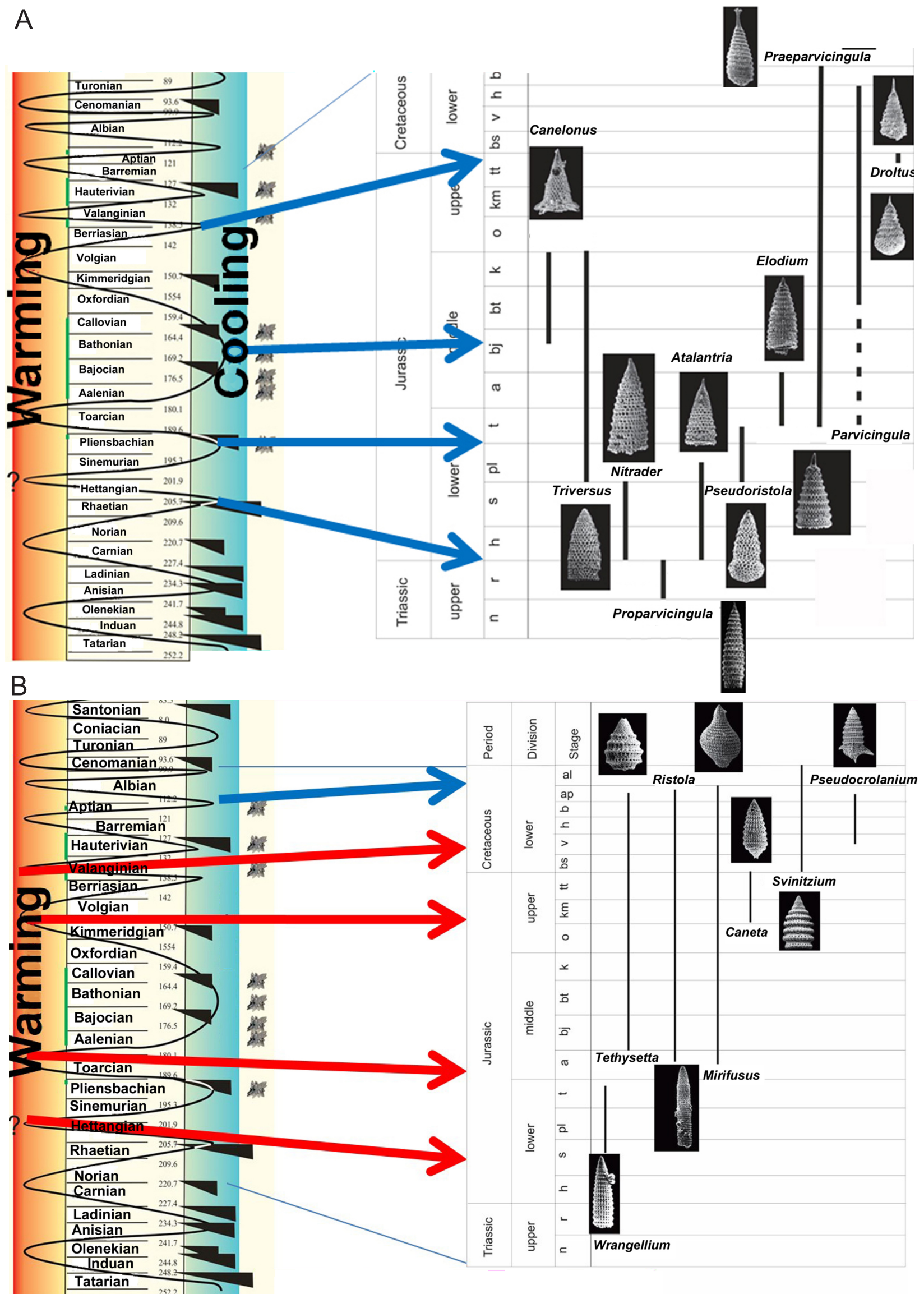

Fig. 6. The evolution of the family Parvicingulidae and the possible relationship with climate

A - stratigraphic ranges and possible phyletic relationships of the high-conical genera of the Parvicingulidae, and climatic fluctuations;

B - stratigraphic ranges, possible phyletic relationships of the conical-subsphaerical group of the Parvicingulidae, and climatic fluctuations 
railensis Pessagno, Parvicingula khabakovi (Zhamoida), Praeparvicingula rotunda Hull, and Pyramotertonium planocephalum (Kozlova) (Bragin, 2011). The last species was of boreal origin, and it has also been described from the Upper Volgian deposits of the Barents Sea Region and Timan-Pechora Plate (Vishnevskaya and Kozlova, 2012).

The radiolarian assemblage from the Berriasian Buchia okensis Zone in the Lena River delta (Ystannakh Khocho locality) includes Arctocapsula devorata arctica (Vishnevskaya and Murchey), A. cf. constantia Bragin, A. incompta Bragin, Echinocampe aff. aculeatum Bragin, Parviciungula alata Kozlova and Vishnevskaya, P. papulata Kozlova and Vishnevskaya, Praeparvicingula rotunda Hull, and Spinicingula cf. ceratina Kozlova and Vishnevskaya (Vishnevskaya et al., 2014).

The subspecies Arctocapsula devorata arctica (Vishnevskaya and Murchey) was recorded in Upper Volgian clays (ammonite Subditus Zone/Buchia piochii Zone) of the Gorodishche section on the River Volga and in the uppermost Volgian shale of the Bazhenovo Formation in Western Siberia (Vishnevskaya and Murchey, 2002; Vishnevskaya and Kozlova, 2012).

According to Baraboshkin et al. (2015) the base of the Upper Volgian (uppermost Tithonian-Lower Berriasian) in the Russian Platform should be defined by the appearance of the genus Kachpurites. Thus, the first appearance of species of the endemic family Echinocampidae Bragin is fixed at the Craspedites subditus Zone of the Gorodishche section (Vishnevskaya and Baraboshkin, 2001). The Tithonian/Berriasian boundary falls somewhere in M19n, perhaps in the local Taimyrensis ammonite Zone (Schnabl et al., 2015), where radiolarians were described below and above in the Nordvik section (Bragin, 2011) and thus, in terms of international stages, part of the "Upper Volgian" is Tithonian and part is Berriasian (Wimbledon et al., 2011, 2013).

Episodes of significant decrease in taxonomic diversity of radiolarians and ammonites in the Late Jurassic within boreal regions were synchronous in both groups (Mitta and Vishnevskaya, 2006). The Late Volgian crisis coincided with significant changes in the morphotypes of ammonite and radiolarian skeletons. A typical Lilliput effect of the latest Middle Volgian boreal ammonite faunas was described by Rogov (2015). The specimens of the latest Middle Volgian/Late Volgian cyrtoidal Nassellaria (Parvicingula, Spinicingula) also have lilliput size, small reticular pores, weak distinct ridges or almost no external circumferential ridges. Also, the decrease in the number of chambers was fixed among the Nassellaria in Late Volgian representatives of the genera Parvicingula, Spinicingula and Stichocapsa. Some extinction of radiolarians began at the end of the Jurassic and most likely resulted from a marine regression and climatic cooling. This is supported by the predominance of cold-water representatives of the genus Parvicingula in radiolarian associations and of the boreal ammonite family Craspeditidae at that time in the Middle Russian, Timan-Petchora and West Siberian Seas (Mitta and Vishnevskaya, 2006; Vishnevskaya and Kozlova, 2012). The rapid evolution of Radiolaria and a bloom of morphological diversity of Parvicingula with the development of numerous abnormal skeletons may have been caused by stress conditions, as was proposed for the "Lilliput effect" in ammonites Rogov (2015). Probably, only the more accommodated, often-primitive, vulgar forms of Parvicingula and Stichocapsa survived to give rise to new trends (Spinicingula and others) and provide evolutionary progress.

The change of the Jurassic Parvicingula-rich assemblage into Echinocampe, Nordvikella and Spinicingula-rich assemblages is observed at the Jurassic-Cretaceous boundary. Just at the Jurassic-Cretaceous boundary (base of the Berriasian), the occurrence of Thanarla, Mita, Dictyomitra, Neorelumbra Quasicrolanium-Pyramotertonium groups has been recorded among radiolarians.

The degree of endemism in high conical Parvicingulidae Pessagno and Echinocampidae Bragin is related to a great abundance of morphotypes with external cephalic spines and apophyses (Vishnevskaya and Kozlova, 2012) at the Jurassic-Cretaceous boundary in boreal regions.

As radiolarians are so common as to be rock formers in the Bazhenovo shale, and other fauna is practically absent, biostratigraphic subdivision is possible only using radiolarians. Because all radiolarian assemblages, used before in the regional scheme of Western Siberia, have been described on the basis of thin section study only, local zonal indices were recognized as not valid (O'Dogherty et al., 2009), and there is a need for the application of a new technique. Application of the tomography method has allowed the recognition of 5 stratigraphic divisions, named as radiolarian biohorizons. All biohorizons are founded on evolutionary changes in the genus Parvicingula.

The lower biohorizon in the Abalak suite (of Siberia) with Parvicingula elegans is Kimmeridgian. The biohorizon of Parvicingula blowi (Lower Tithonian) is established in a siliceous and carbonate interval at the bottom of the Bazhenovo shale with rare Dorsoplanites ilovaiskii Mesezhnikov (Panchenko et al., 2016). Top: last occurrence of Zhamoidellum ovum Dumitrica in the Lower Tithonian (Fig. 9) and Parvicingula blowi as corporeal taxa in the Lower Tithonian (Vennari and Pujana, 2017).

The biohorizon of Parvicingula jonesi (Middle Tithonian) is established in clays and siliceous radiolarites with rare Laugeites groenlandicus Spath and Epilaugeites cf. vogulicus (llovaisky). Bottom: first appearance of Parvicingula jonesi Pessagno, P. excelsa Pessagno and Blome. Top: last occurrence of Praeparvicingula gracila Hull in the Middle Tithonian.

The Parvicingula haeckeli biohorizon (Upper Tithonian) lies in the Bazhenovo shale in carbonate and siliceous radiolarites with Praechetaites exoticus (Schulgina, 1967) (Panchenko et al., 2016). Bottom: first appearance of Parvicingula haeckeli (Pantanelli), P. rothwelli Pessagno. Top: last occurrence of Parvicingula blomei Yang, $P$. colemani Pessagno et Blome in the Tithonian.

The Parvicingula khabakovi biohorizon (Lower Berriasian) with Echinocampidae are identified at the limestone and clay chert level in the Bazhenovo shale with Craspedites taimyrensis (Bodyl.), Chetaites chetae Schulgina (Panchenko et al., 2015, 2016). Bottom: first appearance of Parvicingula khabakovi (Zhamoida), Arctocapsula incompta Bragin, A. perforata Bragin, Echinocampe? aculeatum Bragin, Pyramotertonium planocephalum (Kozlova).

The Williriedellum salymicum biohorizon (Upper Berriasian-Valanginian) with Williriedellum, Echinocampidae are identified at the highest level in the Bazhenovo shale with Buchia okensis (Pavlov) and B. volgensis (Lahusen) (Panchenko et al., 2015, 2016).

The radiolarian biohorizons may be considered as biozones (Vishnevskaya, 2013, 2016). Bottom: first appearance of Tricolocapsa campana Kiessling, Williriedellum salymicum salymicum Kozlova. Top: last occurrence of Parvicingula khabakovi (Zhamoida). The Williriedellum species amount to $70 \%$ within this biohorizon.

The decrease in diversity of the Parvicingulidae at about the Jurassic-Cretaceous boundary, as well as the bloom of the Williriedellidae, with their hyper-thick skeletal wall and submerged cephalothorax, coincides with and probably reflect environmental or hydrological stress. 

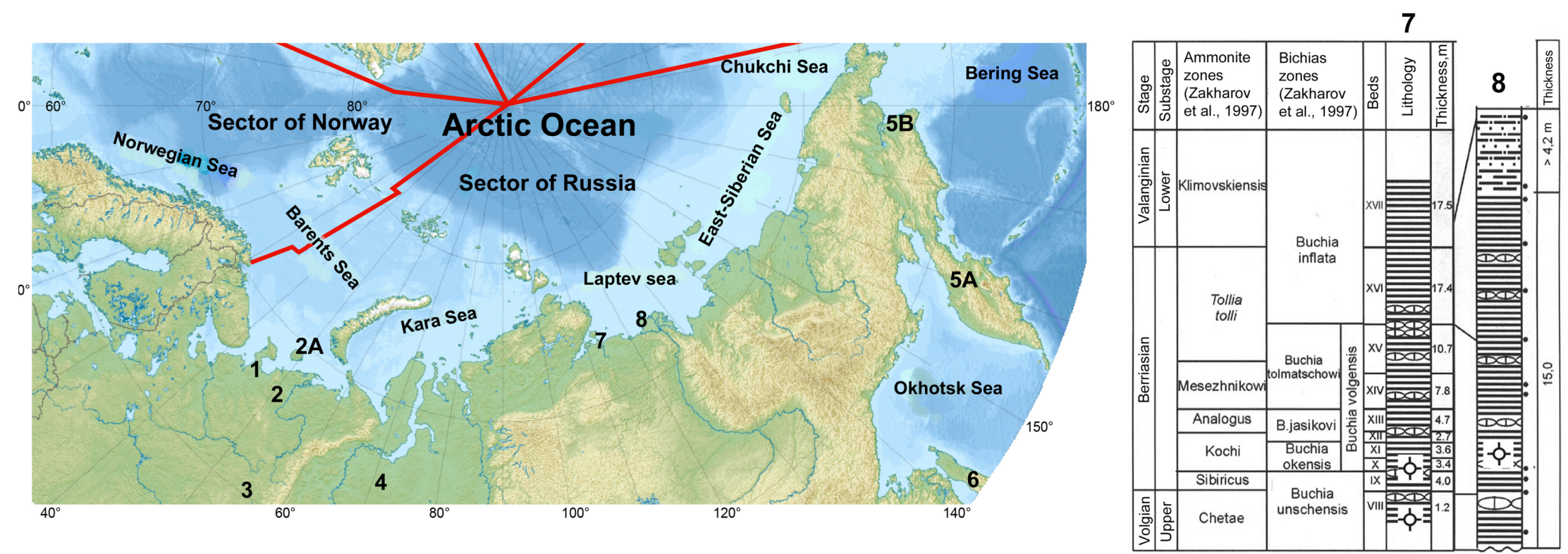

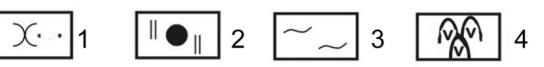

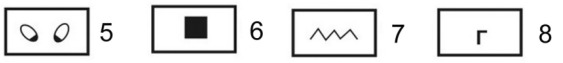

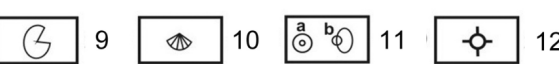
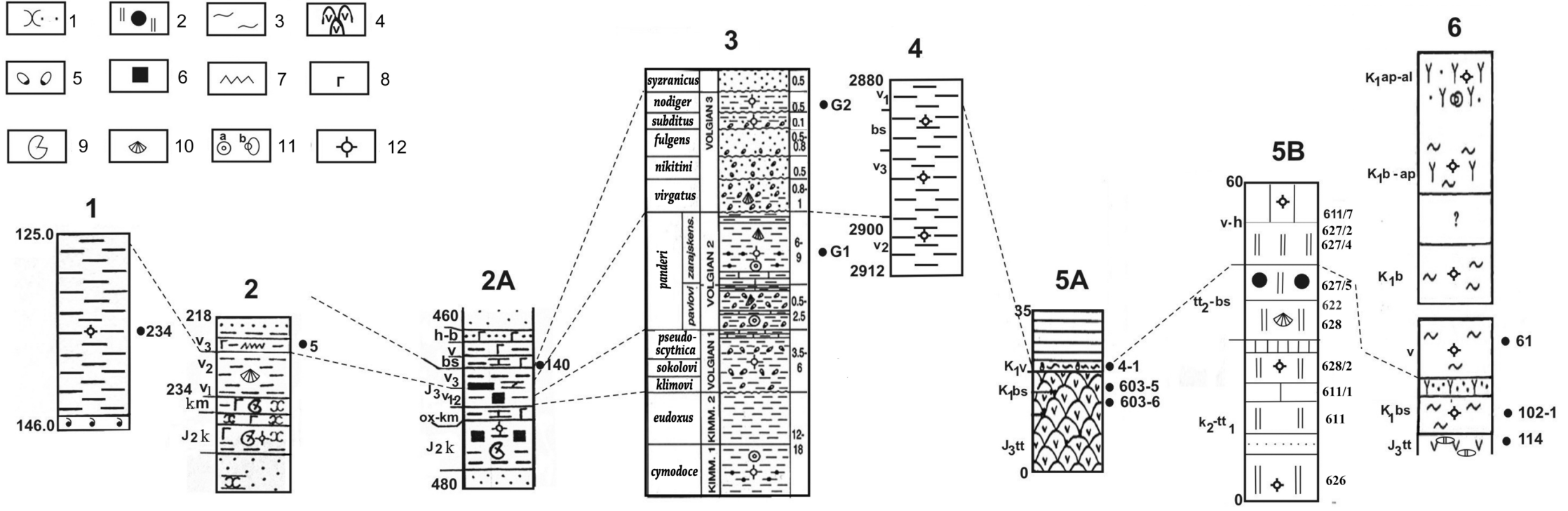

Fig. 7. Correlation of Upper Jurassic and Cretaceous sequences from the Barents-Pechora region to Sakhalin in the far east of the Pacific Margin

Localities: 1 - Mezen Basin, Pesha section; 2 - southeastern Barents-Pechora Basin (2 - Narjan-Mar, borehole 5; 2A - Kolguev, borehole 140); 3 - Volga-Pre-Ural Basin (3 - Gorodishche section, Uljanovsk region); 4 - northern and Western Siberian basins (4 - Upper Salym, borehole 17); 5 - western Kamchatka and Chukotka (5A - Omgon; 5B - Semiglawaya Mountains); 6 - Sakhalin; 7 Nordvik (after Bragin, 2011: Marinov, 2014); 8 - Lena Delta (after Vishnevskaya et al., 2014). Abbreviations for Jurassic: $\mathrm{k}$ - Callovian; km - Kimmeridgian; ox - Oxfordian; tt - Tithonian; v - Volgian regional stage. Abbreviations for Cretaceous: al - Albian; ap - Aptian; $b$ - Barremian; bs - Berriasian; $h$ - Hauterivian; $v$-Valanginian. Age and depths indicate at the left and samples numbers at the right of the column; 1-5, 7, 8 - radiolaria-bearing Boreal sequences with predominance of Parvicingula; 6 - Tethyan affinity with Ristola. Legend: 1 - sand and sandstone, $2-$ chert and chert concretion, $3-$ jasper, 4 - basalt, 5 - phosphatic pebbles, 6 - pyrite, 7 - trace of fossil, 8 - organic detritus, 9 - ammonite, 10 - Bichias, 11 - foraminifera: a - benthic, b - planktonic, 12 - radiolarians. For other explanations see Figure 9 


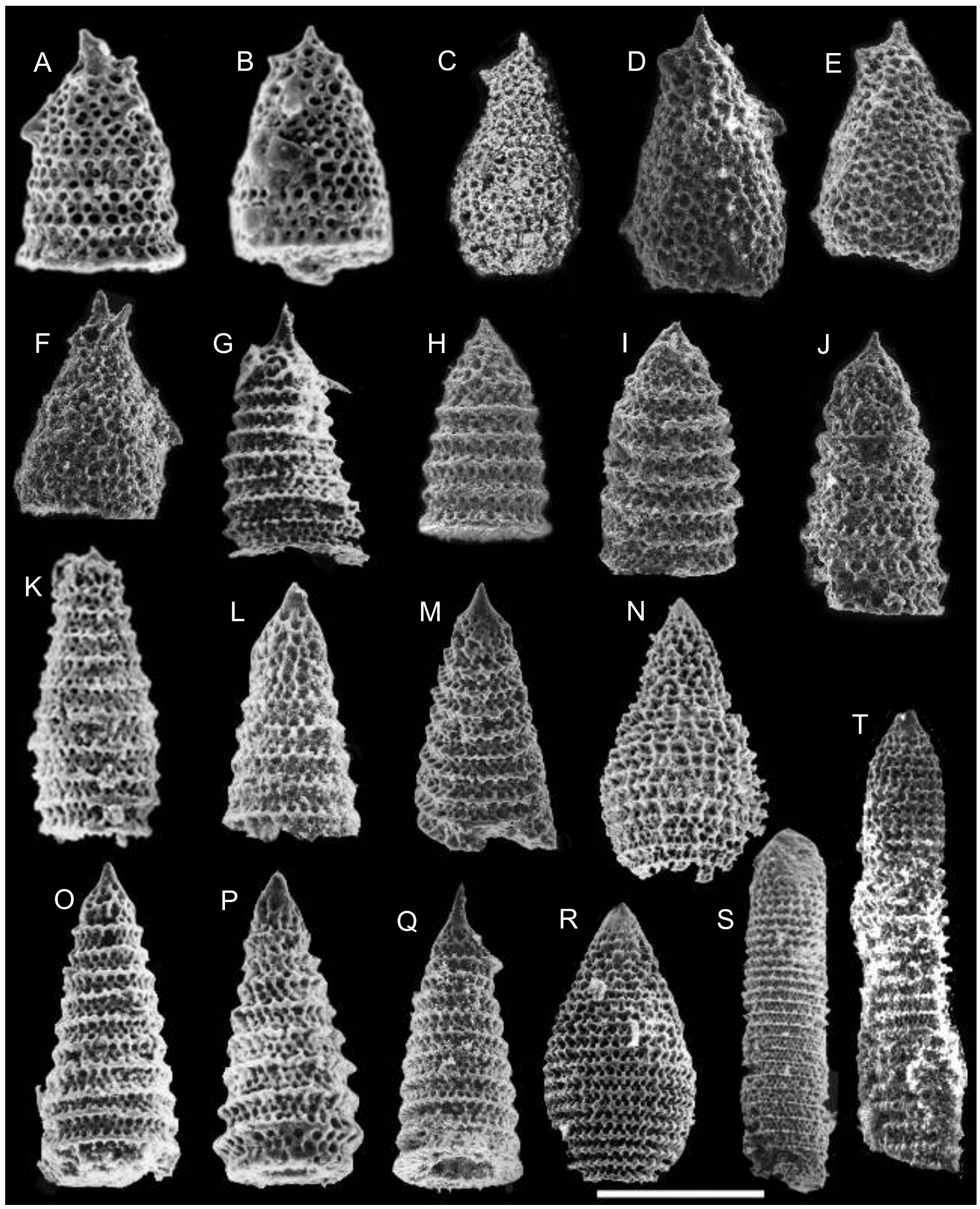

Fig. 8. Scanning electron photomicrographs of Late Jurassic to Early Cretaceous radiolarians from siliceous clay rocks (A, B, K, M - Barents Sea region, C-F, H-J - Lena Delta), tuffaceous jaspers (G, L, N-T - Bering Sea region) in northern Russia

A, B - Spinicingula ceratina Kozlova and Vishnevskaya, Narjan-Mar, borehole 5, Upper Volgian; C - Arctocapsula incompta Bragin; D, E A. devorata arctica (Vishnevskaya et Murchey); $\mathbf{F}-$ Echinocampe aff. aculeatum Bragin; $\mathbf{G}-$ Parviciungula aff. proiecta Kiessling; $\mathbf{H}-P$. papulata Kozlova et Vishnevskaya; I - P. alata Kozlova et Vishnevskaya; $\mathbf{J}-$ Praeparvicingula rotunda Hull; $\mathbf{K}-P$. jonesi $P$ essagno, $\mathbf{L}-P$. gemmata Hull; $\mathbf{M}-$ P. rothwelli Pessagno; $\mathbf{N}$ - Mirifusus guadalupensis Pessagno; $\mathbf{O} \mathbf{Q}-P$. colemani Pessagno et Blome; $\mathbf{R}-$ Mirifusus mediodilatatus (Rüst); S, T - Ristola altissima (Rüst). Scale bar 100 m. A, B - Narjan-Mar, borehole 5, Upper Volgian; C-F, H-J - locality Lena Delta, Berriasian; G - Koryak Mountains, Nauchiranay, Tithonian; K, M - Mezen Basin, Pesha River section, borehole 234, Middle Volgian; L, N-T - Koryak Mountains, Nauchiranay, Tithonian 


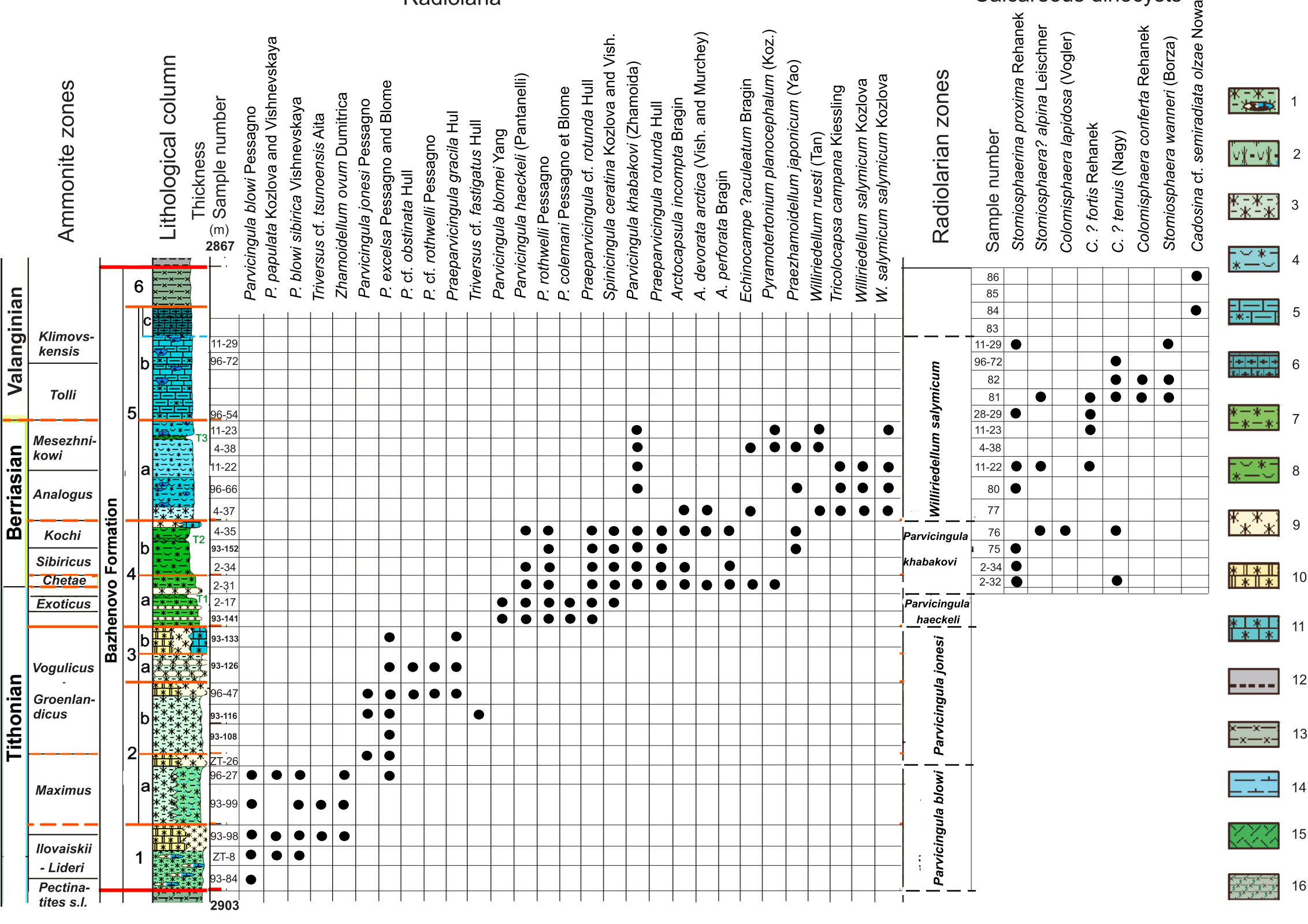

Fig. 9. Range chart of radiolarians and calcareous dinoflagellate cysts in the Bazhenovo Formation of Western Siberia

1 - bituminous clay with radiolarite lens, 2 - clay with calcareous detritus, 3 - bituminous clay, 4 - bituminous clayey limestone with bivalves, 5 - clayey limestone, 6 - clayey limestone with pyrite, 7 - high bituminous clay, 8 - bituminous clay with bivalves, 9 - radiolarite, 10 - radiolarite partly replaced by dolomite, 11 - radiolarite partly replaced by calcite, 12 - clay, 13 - siliceous clay, 14 - marl, 15 - tuff, tuffite, 16 - siliceous clay with glauńonite, T1, T2, T3 - tuffic horizons 
Thus, an abundance of Parvicingula within the oil shale sequences of the Arctic Margin (Dyer and Copestake, 1989; Vishnevskaya and Kozlova, 2012; Vishnevskaya et al., 2014; Vishnevskaya, 2016) provides a basis for establishing a preliminary boreal zonation at the Tithonian-Berriasian boundary: that is, the $P$. haeckeli (Tithonian), and Parvicingula khabakovi (Lower Berriasian) Zones.

\section{CALCAREOUS DINOFLAGELLATES AS POSSIBLE SECONDARY MARKERS}

Zonal schemes using calcareous dinoflagellate cyst have been widely proposed in the Tethys realm (Balkans, Carpathians, Spain, Indian Ocean) within an Upper Jurassic (from Oxfordian) to Lower Cretaceous (up to Albian) interval (Reháková, 2000; Michalík and Reháková, 2011) and applied to other regions (Lakova et al., 1999; Petrova et al., 2012).

Calcareous dinoflagellate cysts (before named as "calcisphaerulides") are common (Figs. 9-13) in the above-described Parvicingula khabakovi biohorizon (Berriasian) and Williriedellum salymicum biohorizon (Upper Berriasian-Valanginian) of the Bazhenovo Formation. They co-occur together with Williriedellum, Echinocampidae, where rare finds of nannoplankton have also been recorded. The abundant representatives of Pithonella occur in the limestone and shale of Berriasian age (Figs. 10 and 11). Pithonella cf. ovalis (Kaufmann) and Stomiosphaerina proxima Rehánek (Fig. 12) have been observed in the Parvicingula khabakovi biohorizon (Berriasian).

Probably, it will be possible to recognize calcareous dinocyst zones of Colomisphaera tenuis and $C$. fortis in the Upper Tithonian and Stomiosphaerina proxima and Stomiosphaera wanneri in the Berriasian, as well as Colomisphaera conferta in the Valanginian of the Bazhenovo Formation (Fig. 13) with progress in new investigations of calcareous dinoflagellate cysts. The comparison with Jurassic to Cretaceous boundary sequences of the European part of Russia indicates some biohorizons in the Gorodishche section of the Volga-Pre-Ural Basin (Vishnevskaya and Baraboshkin, 2001). The Jurassic to Cretaceous boundary sequences of central Europe (e.g., the

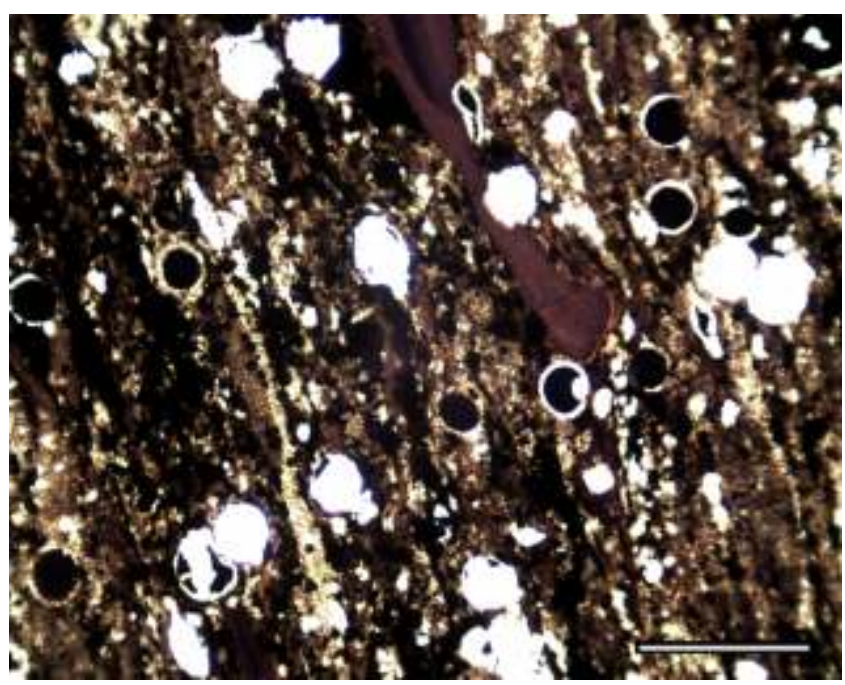

Fig. 10. Calcareous dinoflagellate cysts of the Williriedellum salymicum biohorizon of the Bazhenovo Formation together with Williriedellidae; sample 11-29, Western Siberia, Berriasian-Valanginian; scale bar $100 \mathrm{~m}$

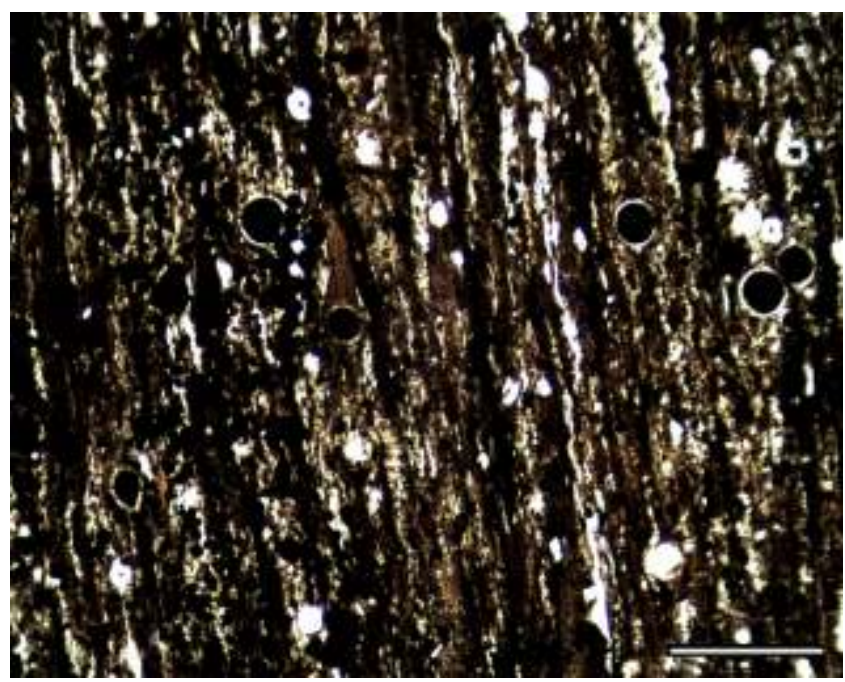

Fig. 11. Calcareous dinoflagellate cysts in Williriedellum salymicum biohorizon of the Bazhenovo Formation; sample

11-23, Western Siberia, Berriasian; scale bar 100 m

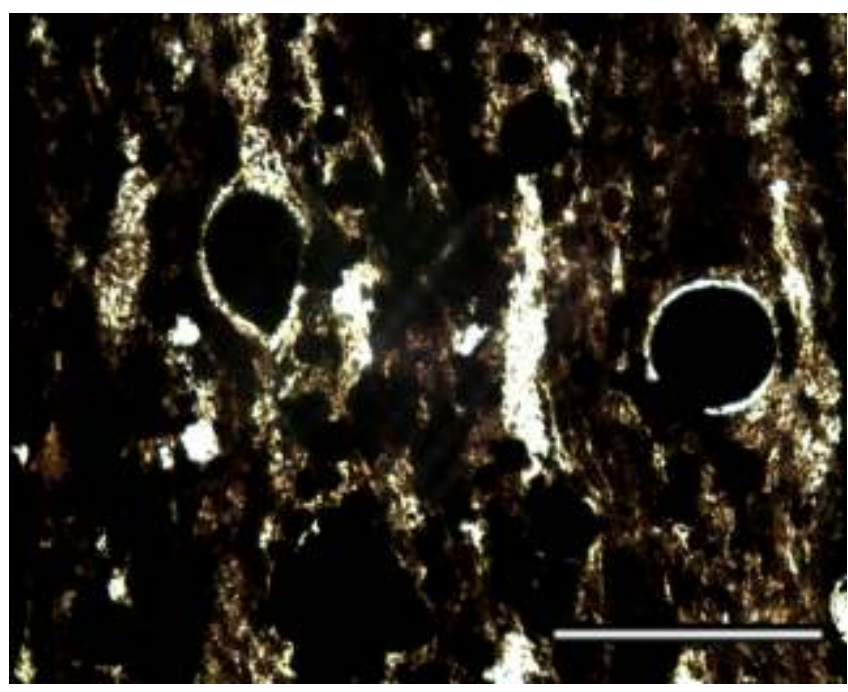

Fig. 12. Calcareous dinoflagellate cysts Pithonella cf. ovalis (Kaufmann) (left side) and Stomiosphaerina proxima Rehánek (right side) in Williriedellum salymicum biohorizon of the Bazhenovo Formation; sample 11-22, Western Siberia, Berriasian; scale bar $100 \mathrm{~m}$

Strapkova section; Michalík et al., 2016) are also characterized by a change from limestone containing radiolarians belonging to the Parvicingulidae into limestone with pithonellids and radiolarians of the Williriedellidae (Vishnevskaya, 2016).

\section{CONCLUSIONS}

Due to radiolarian provincialism the correlation of radiolarian biozones between boreal (northern Eurasia and America) and Tethyan regions (southern Europe: Baumgartner et al., 1995; Hardenbol et al., 1998) is hampered in the Late Jurassic-Early Cretaceous interval. Nevertheless, it is possible to use the Pacific zonation (where the boreal Parvicingula occurs to- 

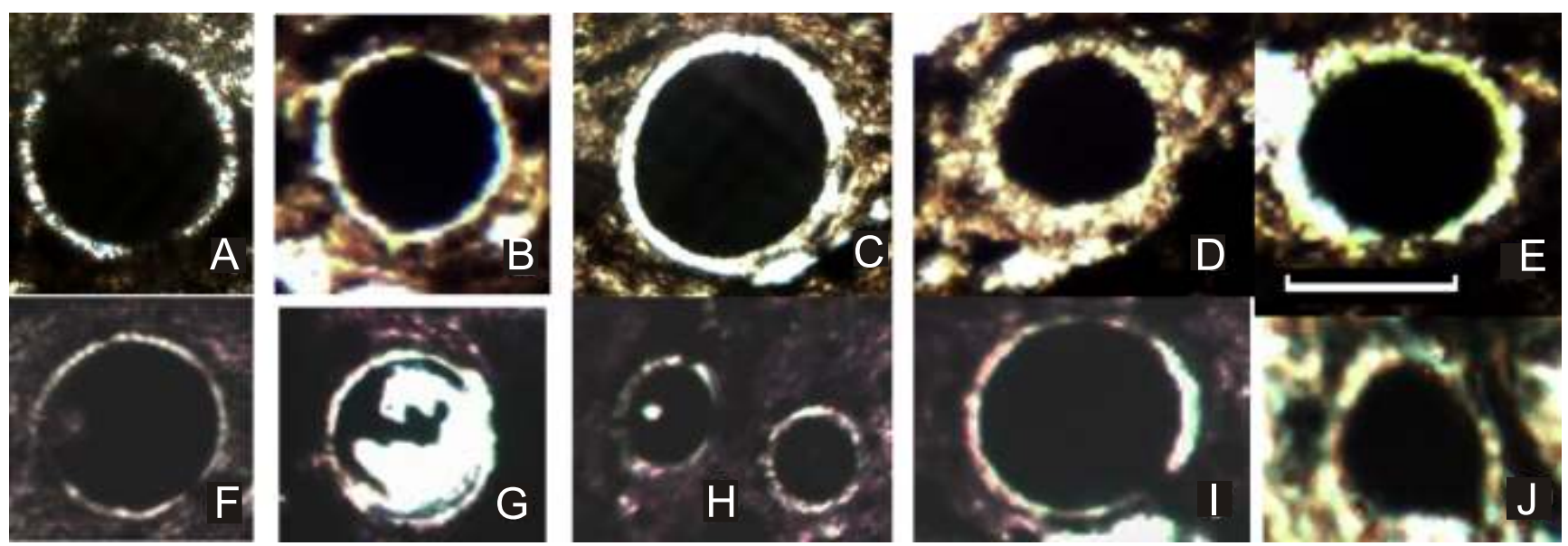

Fig. 13. Calcareous dinoflagellate cysts

A, B - Stomiosphaerina cf. proxima Rehánek (A - sample ZU-308-30, Western Siberia, Berriasian-Valanginian; B - sample 96-72, Western Siberia, Berriasian-Valanginian); C - Colomisphaera ?fortis Rehanek, sample 11-23, Western Siberia, Berriasian; D - Stomiosphaera wanneri (Borza), sample 11-29, Western Siberia, Berriasian-Valanginian; E - Colomisphaera?tenuis (Nagy), sample 2-32-2, western Siberia, Berriasian; F, G - Stomiosphaera? alpina Leischner (F - sample 76, Western Siberia, Berriasian; G - sample 81, Western Siberia, Berriasian-Valanginian); H, I - Colomisphaera conferta Rehanek, sample 81, Western Siberia, Berriasian-Valanginian; J - Calpionella? sp., sample 2-32-2, Western Siberia, Berriasian; scale bar 30 m

gether with the Tethyan genera Mirifusus and Ristola) as the link to correlate Tethyan and boreal scales.

The high-conical representatives of the families Parvicingulidae and Echinocapsidae have key stratigraphic significance at the Jurassic-Cretaceous boundary. The appearance of a group of high-conical parvicingulids at the Triassic-Jurassic boundary in high latitudes of the Northern Hemisphere was most likely due to global cooling. In the course of the Jurassic to the beginning of the Early Cretaceous, this group evolved, spreading across the high latitudes of the entire Pacific palaeogeographic province, and even penetrating into the Arctic and Antarctic regions.

We prove the ubiquitous presence of the Jurassic-Early Cretaceous radiolarian genus Parvicingula in the Bazhenovo, Pechora and the Russian seas, which supports the existence of the northern pathway, bringing a large number of members of this genus from the Pacific palaeoclimatic province into the Arctic and the North Atlantic and South Boreal up to Gorodishche section of the Volga-Pre-Ural Basin.

The abundant presence of Parvicingula within the oil shale sequences of the Russian Arctic margin and the application of tomographic methods provides a basis for establishing a preliminary boreal zonation: Parvicingula elegans (Lower Kimmeridgian), P. blowi (Lower Tithonian), P. jonesi (Middle Tithonian), $P$. haeckeli (Upper Tithonian), P. khabakovi (Berriasian) and Williriedellum salymicum biohorizon (Upper Berriasian-Valanginian) zones.
The radiolarian events at the Jurassic-Cretaceous boundary in the Russian boreal region can be used as an additional biomarker to help develop new integrated boundary criteria. In addition, sections through the Bazhenovo Formation are often characterized by a range of calcareous dinocysts previously repeatedly recorded as "calcisphaerulides". According to the Tethyan calcareous dinocyst zonal scheme (Reháková, 2000), in which the first occurrence of the zonal species Stomiosphaerina proxima coincides with the first appearance of Calpionella alpina, it is logical to propose calcareous dinocysts as a secondary marker.

Acknowledgements. I am thankful to V.V. Zlobin (Geological Institute, Russian Academy of Sciences) for help with microphotography, to Drs. N.Yu. Bragin (GIN RAS), E.O. Amon, M.S. Afanasieva (Palaeontological Institute RAS) for valuable discussions, useful advice, and remarks. I appreciate Dr. M. Bąk, B. Wimbledon and an anonymous reviewer constructive comments which greatly helped to improve a first version of the manuscript. B. Wimbledon made valuable suggestions and comments on the English to improve this investigation. This research was supported by the Russian Foundation for Basic Research, project nos. 15-05-04700, the Programme of the Presidium of the Russian Academy of Sciences "The Origin and Evolution of the Biosphere" and no. 116032510034 of GIN RAN.

\section{REFERENCES}

Afanasev, I.S., Gavrilova, E.V., Barun, E.M., Kalmikov, G.A., Balushkina, N.S., 2010. The Bazhenov Suite: unlocking the potential. Rogtec Exploration. Rosneft, 4: 20-25.

Baraboshkin, E.Yu, Guzhikov, A.Yu., Manikin, A.G., Pimenov, M.V., 2015. Bio- and magnetostratigraphic data on the Jurassic/Cretaceous boundary of the Kashpir and Gorodischi sec- tions (Volga region, Russia). Proceedings volume: The International Scientific Conference on the Jurassic/Cretaceous boundary (eds. E.Yu. Baraboshkin and D.E. Bykov): 25-31. September 7-13, 2015, Samara (Russia). Togliatti, Kassandra.

Baumgartner, P.O., 1984. A Middle Jurassic-Early Cretaceous low-latitude radiolarian zonation based on Unitary Associations 
and age of Tethyan radiolarites. Eclogae Geologicae Helvetiae, 77: 729-837.

Baumgartner, P.O., INTERRAD Jurassic-Cretaceous Working Group, 1995. Middle Jurassic to Lower Cretaceous Radiolaria of Tethys. Mémoires de Géologie (Lausanne), 23.

Bragin, N.Y., 2009. Echinocampidae - new family of Radiolaria of Late Jurassic-Early Cretaceous of the Arctic Siberia (in Russian with English summary). Paleontologičeskij Žurnal, 4: 6-17.

Bragin, N.Y., 2011. Radiolarians of the Volgian and Berriasian stages of the north of Central Siberia. Stratigraphy and Geological Correlation, 19: 173-187.

De Wever, P., Dumitrica, P., Caulet, J.-P., Nigrini, C., Caridroit, M., 2001. Radiolarians in the Sedimentary Record. Amsterdam, Springer.

Dyer, R., Copestake, P., 1989. A review of latest Jurassic to earliest Cretaceous Radiolaria and their biostratigraphic potential to petroleum exploration in the North Sea. In: Northwest European Micropaleontology and Palynology (eds. D.J. Batten and M.C. Keen): 213-235. British Micropalaeontological Society, London.

Hardenbol, J., Thierry, J., Farley, M.B., Jacquin, Th., de Graciansky, P.-C., Vail, P.R. (with numerous contributors), 1998. Mesozoic and Cenozoic sequence chronostratigraphic framework of European basins. SEPM Special Publication, 60 : $3-13,763-781$, and chart supplements.

Hull, D.M., 1997. Upper Jurassic Tethyan and southern Boreal radiolarians from western North America. Micropaleontology, $\mathbf{4 3}$ (Supplement 2): 1-202.

Kiessling, W., 1999. Late Jurassic radiolarians from the Antarctic Peninsula. Micropaleontology, 45: 1-96.

Kiessling, W., Scasso, R., Zeiss, A., Riccardi, A., Medina, F., 1999. Combined radiolarian-ammonite stratigraphy for the Late Jurassic of the Antarctic Peninsula: implications for radiolarian stratigraphy. Geodiversitas, 21: 687-713.

Lakova, I., Stoykova, K., Ivanova, D., 1999. Calpionellid, nannofossil and calcareous dinocyst bioevents and integrated biochronology of the Tithonian to Valanginian in the Western Balkanides, Bulgaria. Geologica Carpathica, 50: 151-168.

Marinov, V.A., 2014. Berriasian Foraminifera from Lena River Delta. Cretaceous system of Russia and the near abroad: problems of stratigraphy and paleogeography. Proceedings of the Seventh Russian Scientific Conference with International Participation, Vladivostok: 197-201.

Mekik, A.F., 2000. Early Cretaceous Pantanelliidae (Radiolaria) from northwest Turkey. Micropaleontology, 46: 1-30.

Mekik, A.F., Ling, H.Y., Özkan-Altiner, S., Altiner, D., 1999. Preliminary radiolarian biostratigraphy across the Jurassic-Cretaceous Boundary from northwestern Turkey. Geodiversitas, 21 : 715-738.

Michalík, J., Reháková, D., 2011. Possible markers of the Jurassic/Cretaceous boundary in the Mediterranean Tethys: a review and state of art. Geoscience Frontiers, 2: 475-490.

Michalík, J., Reháková, D., Grabowski, J., Lintnerová, 0. Svobodová, A., Schlögl, J., Sobień, K., Schnabl, P., 2016. Stratigraphy, plankton communities, and magnetic proxies at the Jurassic/Cretaceous boundary in the Pieniny Klippen Belt (Western Carpathians, Slovakia). Geologica Carpathica, 67: 303-328.

Mitta, V.V., Vishnevskaya, V.S., 2006. Dynamics of the evolution of ammonites and radiolarians and anoxic events in the terminal Jurassic on the Russian Platform (in Russian). In: Cephalopoda 2006 (ed. T.B. Leonova): 55-63. PIN RAN, Moskva.

Nakrem, H.A., Kiessling, W., 2012. Late Jurassic (Volgian) radiolarians from Central Spitsbergen - a preliminary study. Norwegian Journal of Geology, 92: 149-155.

O'Dogherty, L., Carter, E.S., Dumitrica, P., Goričan, Š., De Wever, P., Bandini, A.N., Baumgartner, P.O., Matsuoka, A., 2009. Catalogue of Mesozoic radiolarian genera. Part 2: Jurassic-Cretaceous. Geodiversitas, 31: 271-356.

Panchenko, I.V., Balushkina, N.S., Baraboshkin, E.Yu., Vishnevskaya, V.S., Kalmikov, G.A., Shurekova, O.V., 2015. Complexes of paleobiota in Abalak-Bazhenov deposits in the
Central part of Western Siberia (in Russian). Neftegasovaya Geologiya. Teoriya i Praktika, 10: 4-27.

Panchenko, I.V., Nemova, V.D., Smirnova, M.E., Ilina, M.V., Baraboshkin, E.Yu., Ilyin, V.S., 2016. Stratification and detailed correlation of Bazhenov horizon in central part of the Western Siberia due to lithological and paleontological study of the core and well logging (in Russian). Geologia Nefti i Gaza, (6): $36-48$

Pessagno, E.A., 1977. Upper Jurassic Radiolaria and radiolarian biostratigraphy of the California from the radiolarian cherts. Micropaleontology, 23: 231-234.

Pessagno, E.A., Blome, C.D., Hull, D., Six, W.M., 1993. Jurassic Radiolaria from the Josephine ophiolite and overlying strata. Smith River Subterrane (Klamath Mountains), southwestern California and southwestern Oregon. Micropaleontology, 39: 93-166.

Pessagno, E.A. Jr., Hull, D.M., Hopson, C.A., 2000. Tectonostratigraphic significance of sedimentary strata occurring within and above the Coast Range ophiolite (California Coast Ranges) and the Josephine ophiolite (Klamath Mountains) northwestern California. GSA Special Paper, 349: 383-394.

Pessagno, E.A., Cantu-Chapa, A., Mattinson, J.M., Meng, X. Kariminia, S.M., 2009. The Jurassic-Cretaceous boundary: new data from North America and the Caribbean [Part 1 of 4]. Stratigraphy, 6: 185-264.

Petrova, S., Rabrenović, D., Lakova, I., Koleva-Rekalova, E., Ivanova, D., Metodiev, L., Malešević, N., 2012. Biostratigraphy and microfacies of the pelagic carbonates across the Jurassic/Cretaceous boundary in eastern Serbia (Stara Planina-Poreč Zone). Geologica Balcanica, 41: 53-76.

Popova, I.M., Baumgartner, P.O., Filippov, A.N., Khanchuk, A.I., 1999. Jurassic and Early Cretaceous Radiolaria of the Lower Amurian Terrane: Khabarovsk region, far east of Russia. The Island Arc, 8: 491-522.

Reháková, D., 2000. Calcareous dinoflagellate and calpionellid bioevents versus sea-level fluctuations recorded in the west Carpathian (Late-Jurassic/Early Cretaceous) pelagic environments. Geologica Carpathica, 51: 229-243.

Rogov, M.A., 2015. The "Lilliput effect" and the evolution of Late Jurassic Boreal ammonites (in Russian). In: Contributions to current cephalopod research: morphology, systematics, evolution, ecology and biostratigraphy (eds. T.B. Leonova, I.S. Barskov and V.V. Mitta): 46-48. Proceeding of conference, Moscow, 2-4 April, 2015. Russian Academy of Sciences, Borissiak Paleontological Institute.

Schnabl, P., Pruner, P., Wimbledon, W.A.P., 2015. A review of magnetostratigraphic results from the Tithonian-Berriasian of Nordvik (Siberia) and possible biostratigraphic constraints. Geologica Carpathica, 66: 489-498.

Vasileva, E.L., 2015. On the Jurassic/Cretaceous boundary in the decisions of the Interdepartmental Stratigraphic committee. Proceedings volume: The International Scientific Conference on the Jurassic/Cretaceous boundary (eds. E.Yu. Baraboshkin and D.E. Bykov): 77-82. September 7-13, 2015, Samara (Russia). Togliatti, Kassandra.

Vennari, V.V., Pujana, I., 2017. Finding of two new radiolarian associations calibrated with ammonoids in the Vaca Muerta Formation (Late Jurassic-Early Cretaceous), Neuquen Basin, Argentina. Journal of South American Earth Sciences, 75: 35-50.

Vishnevskaya, V.S., 1993. Jurassic and Cretaceous radiolarian biostratigraphy in Russia. Micropaleontology, Special Publication, 6: 175-200.

Vishnevskaya, V.S., 1997. Development of Palaeozoic-Mesozoic Radiolaria in the northwestern Pacific Rim. Marine Micropaleontology, 30: 79-95.

Vishnevskaya, V.S., 1998. The Domanikoid facies of the Russian Platform and the basin paleogeography. Mémoires du Muséum National d'Histoire Naturelle (Paris), 177: 45-69.

Vishnevskaya, V.S., 2001. Jurassic and Cretaceous Radiolarian Biostratigraphy of Russia. Moscow, GEOS. 
Vishnevskaya, V., 2012. Evolution of the Family Parvicingulidae (Radiolaria) and climatic fluctuations. Radiolaria Newsletter, 28: 193-195.

Vishnevskaya, V.S., 2013. Biostratigraphy and paleogeography of the Bazhenovo Formation based on radiolarian analysis (in Russian). Jurassic System of Russia: problems of stratigraphy and paleogeography. Fifth All-Russian meeting. September 23-27, 2013, Tyumen. Research materials (eds.V.A. Zakharov M.A. Rogov, B.N. Shurigin): 34-37. Yekaterinburg, Izdat Nauka Servis.

Vishnevskaya, V.S., 2016. Age of the oil siliceous-limestone sequences of the Bazhenovo Formation from Western Siberia based on radiolarian analysis (in Russian). Problems of regional geology of the North Eurasia. Research materials of Conference 14-15 April, 2016. Moscow, MGRI-RGGRU: 22-24.

Vishnevskaya, V.S., Baraboshkin, E.Yu., 2001. New data on biostratigraphy of the Volgian Stage lectostratotype near the Gorodishche Village (Middle Volga Region). Stratigraphy and Geological Correlation, 9: 491-500.

Vishnevskaya, V.S., Filatova, N.I., 2012. Allochthonous Mesozoic marine sequences of Northeastern Asia and Western North America: correlation of the stratigraphic levels. Russian Journal of Pacific Geology, 6: 189-208.

Vishnevskaya, V.S., Filatova, N.I., 2016. Sedimentary settings of marine Middle Mesozoic allochthonous complexes of Northeastern Asia and their correlation. Stratigraphy and Geological Correlation, 24: 575-592.

Vishnevskaya, V.S., Kozlova, G.E., 2012. Volgian and Santonian-Campanian radiolarian events from the Russian Arctic and Pacific Rim. Acta Palaeontologica Polonica, 57: 773-790.

Vishnevskaya, V.S., Murchey, B.L., 2002. Climatic affinity and possible correlation of some Jurassic to Lower Cretaceous radiolarian assemblages from Russia and North America. Micropaleontology, 48: 89-111.

Vishnevskaya, V.S., Pralnikova, I.E., 1999. Jurassic radiolarians from Northern Russia. Stratigraphy and Geological Correlation, 7: $473-491$
Vishnevskaya, V.S., Amon, E.O., Marinov, V.A., Shurygin, B.N., 2014. A new find of Early Cretaceous radiolarians on the Arctic Coast of East Siberia (Lena River Delta Area). Doklady Earth Sciences, 458: 1047-1051.

Wimbledon, W.A.P., 2008. The Jurassic-Cretaceous boundary: an age-old correlative enigma. Episodes, 31: 423-428.

Wimbledon, W.A.P., Casellato, C.E., Reháková, D., Bulot, L.G., Erba, E., Gardin, S., Verreussel, R.M.C.H., Munsterman, D.K., Hunt, C.O., 2011. Fixing a basal Berriasian and Jurassic/Cretaceous $(\mathrm{J} / \mathrm{K})$ boundary - is there perhaps some light at the end of the tunnel? Rivista Italiana di Paleontologia e Stratigrafia, 117: 295-307.

Wimbledon, W.A.P., Reháková, D., Pszczółkowski, A., Casellato, C.E., Halásová, E., Frau, C., Bulot, L.G., Grabowski, J., Sobień, K., Pruner, P., Schnabl, P., Cížková, K., 2013. A preliminary account of the bio- and magnetostratigraphy of the Upper Tithonian-Lower Berriasian interval at Le Chouet, Drôme (SE France). Geologica Carpathica, 64: 437-460.

Yang, Q., 1993. Taxonomic studies of Upper Jurassic (Tithonian) Radiolaria from the Taman Formation, east-central Mexico. Palaeoworld, 3: 1-164.

Zakharov, V.A., 2010. Boreal climate in Mesozoic (in Russian). Priroda, 4: 37-42.

Zakharov, V.A., Rogov, M.A., 2006. New data on the Jurassic-Cretaceous boundary deposits in the Arctic (Nordvik Peninsula, Northern Siberia). Proceedings of the Third All-Russian Conference "Cretaceous System of Russia and Nearby Countries: problems of Stratigraphy and Paleogeography", Saratov, September 26-30, 2006, Saratov: SO EAGO: 61-63.

Zakharov, V.A., Bogomolov, Yu.I., Ilyina, A.G., Konstantinov, N.V., Kurushin, I.I., Lebedeva, N.K., Meledina, S.V., Nikitenko, B.L., Sobolev, E.S., Shurygin, B.N., 1997. Boreal zonal standard and biostratigraphy of the Siberian Mesozoic. Geologiya i Geofizika, 38: 927-956. 